\title{
The Geological Characteristics and Its Mining Evaluation of Xincheng Gold Deposit in Jiaodong
}

\author{
Zhu Suizhou ${ }^{1}$, Wang Zhihao ${ }^{2}$, Ji Zhigang ${ }^{2}$, Li Jianwei $^{2}$, Liu Yun ${ }^{2}, Z_{h o u ~ Y u^{2}, \text { Zhang Qiuhu }}{ }^{2}$ \\ ${ }^{1}$ Shandong Zhengyuan Geological Resources Exploration Co. Ltd, Jinan, China \\ ${ }^{2}$ Shanong Zhengyuan Geological Survey, Institute of China Metallurgical Geology Bureau, Jinan, China
}

Email address:

Zhusz0208@163.com (Zhu Suizhou)

\section{To cite this article:}

Zhu Suizhou, Wang Zhihao, Ji Zhigang, Li Jianwei, Liu Yun, Zhou Yu, Zhang Qiuhu. The Geological Characteristics and Its Mining Evaluation of Xincheng Gold Deposit in Jiaodong. Earth Sciences. Vol. 10, No. 4, 2021, pp. 165-169. doi: 10.11648/j.earth.20211004.13

Received: May 31, 2021; Accepted: June 26, 2021; Published: August 24, 2021

\begin{abstract}
Xincheng gold deposit is located in Xincheng Village of Jiaodong, Laizhou Jincheng, near Bohai Bay, and is one of the largest mines in China. The orebodies of Xincheng gold deposit located in Jiaojia fault zone are mainly located in the pyrite sericite-quartzized cataclasite belt and the pyrite-sericite-quartzized granodioritic cataclasite belt under the main fault plane (Fault Gouge). Based on the exploration data and test data, the occurrence characteristics of I and V major orebodies in the deposit are analyzed, and the mining evaluation is made on the basis of the hydrologic and environmental characteristics of the deposit. The results show that the rock of the Orebody, roof and floor is mainly massive igneous rock and Metamorphic Rock, which has high mechanical strength and is hard and semi-hard rock with simple engineering geological conditions The Ore and waste rock are not easy to decompose harmful substances, have no heat harm, the possibility of local surface deformation caused by mining is not big, the circulation of groundwater is bad, the evaporation is big, the water quality is bad, the mined-out area formed by mining has little influence on the stability of rock mass in the mining area. The main ore body in the study area is of good geological environment.
\end{abstract}

Keywords: Xincheng Gold Ore, The Characteristics of the Main, Mining Evaluation

\section{Introduction}

Jiaodong Xincheng gold deposit is located in Xincheng village, Jincheng, on the Bank of Bohai Bay. It has been in production since 1980 and belongs to one of the large mines in China. After several decades of mining, the reserve of recoverable resources in the deposit is in crisis. However, with the discovery of I and $\mathrm{V}$ ore bodies, the service life of the mine has been greatly increased. In recent years, the research of I and $\mathrm{V}$ ore bodies has been very active, and the genesis, occurrence, ore-controlling structure, reserves and so on have been studied from different angles [1-11]. On the basis of the research results and combining with the field exploration data and test data, the occurrence characteristics of I and V ore bodies are analyzed more deeply and concretely, combined with the water pattern and environmental characteristics of the mining area, the mining evaluation of the deposit is carried out.

\section{Deposit Geology}

\subsection{Structural Feature}

The Xincheng Mining area is located in the Xincheng segment of Jiaojia fault zone, where the quaternary loose sediments are widely distributed, characterized by the development of fault structures and magmatic rocks, on the east side are the fine medium weak GNEISSIC biotite monzogranite in the Jiuqu unit of Linglong ultraunit and the porphyritic biotite granodiorite in the Shangzhuang Unit of Guojialing ultraunit, on the west side is the coarse-grained biotite Monzonite in the Cui Zhao unit of Linglong super-unit [12]. The regional structure is dominated by the east-west Qixia anticlinal structure, which is located in the central part of the mining area and controls the distribution of the gold ore belt. Since the Yan Mountains Movement, fold structures have not developed, they are mainly fault structures, especially nne-trending fault structures. From West to East, there are 
Sanshan Islands fault, long-lai fault and zhao-ping fault, which distribute in parallel and strike ne-ne, dip north-west or south-east, dip angle $30-70^{\circ}$, long tens of kilometers, wide tens to hundreds of meters, plays an important role in controlling rock gold deposits (table 1).

Table 1. Geological Characteristics of the ne-ne trending faults in the early NE OCATHAYSIAN system.

\begin{tabular}{|c|c|c|c|c|}
\hline \multirow{2}{*}{ Name of fault } & \multirow{2}{*}{ scale xposure length $(\mathrm{km})$} & \multirow{2}{*}{ Width of Fault Zone (m) } & \multicolumn{2}{|l|}{ Attitude } \\
\hline & & & Trends & Trends/Dip \\
\hline Sanshandao Fault & 1.5 & $20-200$ & $\mathrm{NE} 45^{\circ}$ & $\mathrm{SE} 25^{\circ}$ \\
\hline Jiaojia Fault & 20 & $50-300$ & NE40-45 ${ }^{\circ}$ & NW28-45 \\
\hline Hedong-wangershan fault & 9 & $2-200$ & Near SN & NW30-60 \\
\hline Beijie-lingshangoufault & 24 & $1-10$ & NE40-45 ${ }^{\circ}$ & $\mathrm{SE} 45-50^{\circ}$ \\
\hline
\end{tabular}

Table 1. Continued.

\begin{tabular}{lll}
\hline Name of fault & Main lithology and characteristics of fault zones & Major deposits distributed along fault zones \\
\hline \multirow{2}{*}{ Sanshandao Fault } & compressibility, Upper Plate of metamorphic rocks of Jiaodong Group, & Sanshandao Gold Deposits, Cangshang Gold \\
& Lower Plate of Linglong Granite & Deposits \\
Jiaojia Fault & compressibility, Upper Plate of metamorphic rocks of Jiaodong Group, & Matang, jiaojia, hongbu, Xincheng, Hedong, \\
& $\begin{array}{l}\text { Lower Plate of Linglong Granite } \\
\text { compressibility, Mylonite, foliation zone and fault gouge are developed }\end{array}$ & wangershan gold Deposits \\
Hedong-wangershan fault & in the zone & Lingshangou, Beije gold deposits \\
Beijie-lingshangoufault & compressibility, Mylonite, foliation zone and fault gouge & wangershan gold Deposits \\
\hline
\end{tabular}

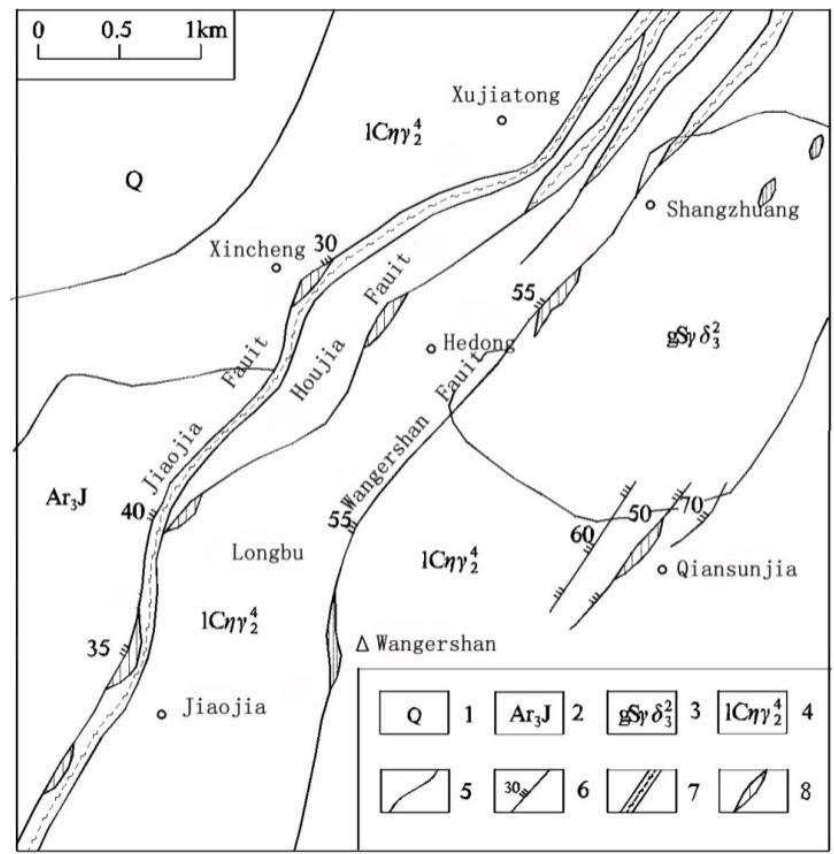

Figure 1. Geological sketch map of Jiaojia structural belt [13].

1-Quaternary; 2-Jiaodong Group; 3-Shangzhuang Unit; 4-CuiZhao Unit; 5-Geological Boundaries; 6-compressive-torsional fracture; 7-Crush Fracture Zone; 8-Gold Mines.

\subsection{Altered Rock}

Wall Rock Alteration is developed in the mining area, and its scale and strength depend on the scale and nature of the fault structure and the degree of rock fragmentation. The alteration types are potash feldspar, pyrite sericitization, carbonation, chlorite, kaolinization and so on. The Wall rock alteration is zonal, and there is no obvious boundary between the zones, and the alteration is gradual and excessive. In plane and section, it is banded, and its occurrence and shape are controlled by the main fault. The ore bodies are mainly located in the pyrite sericite-quartzite cataclasite belt (Figure 2) and the pyrite-sericite-quartzite-granodiorite cataclasite belt (Figure 3), which are the main gold-bearing rock belts, and are collectively referred to as the gold-bearing mineralization belt, secondly, it is sericized granodiorite belt. Fault Gouge (main fracture surface): grey-black, composed of argillaceous and quartz particles, developed in compression foliation, $5 \sim 20 \mathrm{~cm}$ of fault gouge, stable extension of main fracture surface, consistent with fault alteration zone, clear contact line with altered rock, generally located in the upper wall of orebody [2].

\subsection{Characteristics of Deposits}

Since the Xincheng Gold Deposit was discovered in Laizhou, Shandong province, the previously discovered ore bodies are I, II, IV, V, VI, VII, VIII, IX (Upper Plate) and x, and $\mathrm{I}$ and $\mathrm{V}$ are the main ore bodies, the upper and lower footwall of Jiaojia fault zone on the line 111-249 are distributed in parallel, near-equidistant, right-lateral Oblique pattern with obvious south-west volt characteristics. The orebodies are stratiform-stratiform, the surface orebodies are distributed between the lines 177-185, the exposed length is $120 \mathrm{~m}$, the orebodies are distributed between the lines 111-249 on the plane, the orebodies are prone to the side of SW, the lateral recumbent angle is $45^{\circ}$, and the highest elevation is- $1500 \mathrm{~m}$, the ore bodies are located in the footwall of Jiaojia fault near the main fracture surface and controlled by Jiaojia fault and its secondary structure. Overall Trend NE37 ${ }^{\circ}$, dip angle $30^{\circ}$, the engineering control longest trend extends more than 900 meters, the biggest control oblique depth 1480 meters (Figure 4).

Based on exploration data combined with analytical data, the authors analyzed the characteristics of I and V ore bodies:

I orebody surface length $120 \mathrm{~m}$ (between 177 185 lines), the average length $330 \mathrm{~m}$. The ore bodies strike an average of $37^{\circ} \mathrm{NE}$, dip to $\mathrm{NW}$, dip angle of $26-30^{\circ}$, and the maximum 
controlled dip depth of $1440 \mathrm{~m}$. The ore bodies are distributed in the pyrite sericite-dacite cataclasite belt and the pyrite sericized granitic cataclasite belt below the main fracture surface. On the plane, it shows a thick and complicated lenticular and veined shape, with local branch compound, expansion, pinch and pinch, etc.. On the section, it also shows a vein shape, branch compound, pinch and reappear etc.. The thickness of orebody is generally between $2.5 \mathrm{~m}$ and $28.5 \mathrm{~m}$, the average thickness is $13.63 \mathrm{~m}$, and the thickness variation coefficient is $70.36 \%$. The orebody belongs to the thickness variation stable type. The grade is generally between $1-23.2 \times 10^{-6}$, the average grade is $2.86 \times 10^{-6}$, and the grade variation coefficient is $159.83 \%$, it belongs to the ore body with more uniform distribution of useful components. Macroscopically, the orebody has a single shape and good continuity, with a dip angle of $45^{\circ}$ from stratiform to south-west. According to the mineralization intensity of Orebody, the mineralization intensity of surface and deep part of orebody is weak, the grade is relatively low, and the mineralization intensity and thickness are high in the middle part of orebody. From the plane of the Middle Section, the strike length and thickness of the orebody vary greatly, and the branch and compound phenomenon are obvious. Some orebodies occur close to the main fault surface, and some orebodies are some distance away from the main fault surface and controlled by the secondary structure of Jiaojia fault [14].

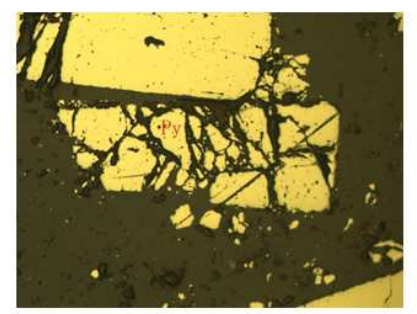

crushed structure (Pyrite crushed) (一) $10 \times 10$

Figure 2. Pyrite sericite-quartzized cataclasite.

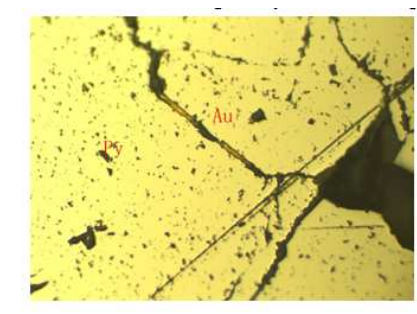

Natural Gold occurs in pyrite fractures (-) $10 \times 20$

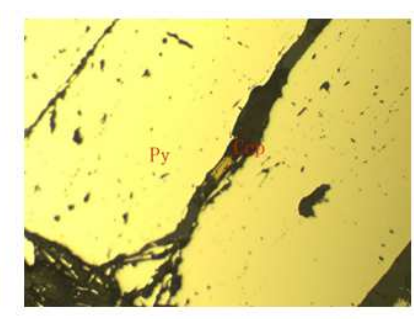

Chalcopyrite occurs in pyrite fractures (一) $10 \times 10$

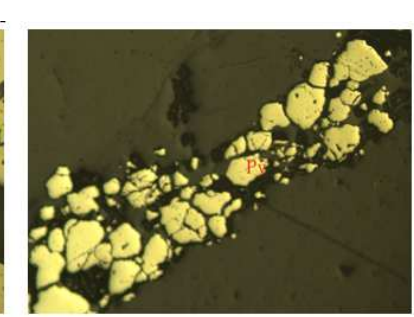

Pyrite occurs in veins in crevices (一) $10 \times 5$

Py-Pyrite Au-Natural Gold Q-Quartz

Figure 3. Pyrite sericized granodiorotic cataclasite.

V Ore bodies are distributed between 165-188 lines below the middle Section of $-430 \mathrm{~m}$ and occur along the dip side of no. I ore body and outside the footwall of Jiaojia fault. Occurring in the pyrite-sericite-quartzite cataclasite belt and the pyrite-sericite-quartzite-granodioritic cataclasite belt under the main fracture surface of the Jiaojia fault alteration zone, the occurrence is wavy in both plane and section, and the

occurrence is basically consistent with that of the main fracture surface, vein-shaped, Complex lens-shaped, with branching compound, expansion and contraction characteristics. The general strike of the orebody is $31^{\circ}$, the dip is nw and the dip angle is $32^{\circ}$. The project control trend is $870 \mathrm{~m}$ long and the control tendency is $1070 \mathrm{~m}$ deep. The orebody did not pinch out along the strike and dip. The orebody lies in the direction of $271^{\circ}$, the dip angle is $64^{\circ}$, and the depth of dip is $706 \mathrm{~m}$. The orebody is layered, the thickness is between $10-30 \mathrm{~m}$, the maximum thickness is 62.5 $\mathrm{m}$, the average thickness is $24.4 \mathrm{~m}$, the thickness change coefficient is $78.92 \%$, the orebody belongs to the thickness change stable type, the grade is between $1-11.8 \times 10^{-6}$, the average is $2.71 \times 10^{-6}$, the grade change coefficient is $132.63 \%$, belongs to the ore body with more uniform distribution of useful components [15].

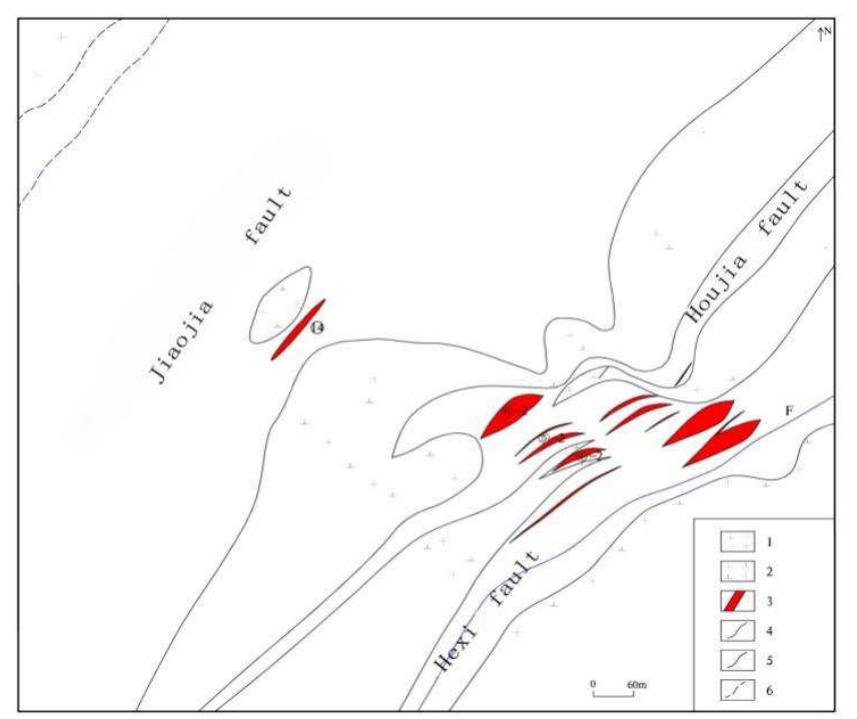

Figure 4. Map of underground vein distribution in Xincheng gold mining area.

1-Adamellite; 2-Diorite; 3-Ore Bodies; 4-Major faults; 5-Geological Boundaries; 6-inferring geological boundaries.

\section{Mining Evaluation}

\subsection{Evaluation of Engineering Geological Conditions}

The rock of the ore body and its top and bottom is mainly the massive igneous rock and metamorphic rock. The mechanical strength of the Rock is high and it belongs to hard and semi-hard rock. The quality grade of rock mass is general, and the block structure is the main one. The stability of orebody roof is poor, and the stability of orebody floor is good. The quaternary structure of the surface layer is loose, and it is a loose structure with poor stability, but it is far away from the ore body and thin in thickness, which has no obvious influence on the mining of the ore deposit. The fault structure of the mining area is simple and the rock fractures are medium.

In a word, the engineering geological exploration type of the deposit belongs to the top, the floor is dominated by the 
massive rock, the roof stability is poor, and the mining work is mainly carried out in the relatively stable footwall, so the type of engineering geological exploration of the deposit belongs to the deposit with simple engineering geological conditions.

\subsection{Geological Hazards That May Arise from the Exploitation of Mineral Deposits}

Although the exploitation of the deposit will drain part of the groundwater in the lower wall of the weak water-rich Aquifer, the water-rich nature of the water-bearing zone is weak, the strength of the rock is high, and there is no soluble material in the deposit, and no large voids or voids will form, drainage will not cause obvious deformation of rock, ground subsidence, collapse and other geological disasters.

The mined-out area formed by ore deposit exploitation has certain influence on the stability of rock mass in the mining area. No. V orebody located under the main fracture face is less continuous, its thickness is small, its horizontal dip does not extend very far, and large mined-out area will not be formed during mining. The roof of the ore body is also the main fracture surface and the sericite-quartzized granitic cataclasite, with low strength, rock fragmentation and poor integrity of the rock body. The roof rock will continuously collapse, forming a certain caving zone, and the height of the caving zone generally does not exceed $20 \mathrm{~m}$, the caving zone will be smaller when backfill method is used. The caving zone is quite far from the ground, and there is no weak structural plane in the roof which is opposite to the dip angle of the main belt. Therefore, the mined-out area formed by mining has little influence on the stability of rock mass in the mining area.

\subsection{Environmental Geology of Mining Areas}

The mining area is located in the northwest of the Jiaodong peninsula and is part of the Jiaodong uplift, an ancient basement. The constituent rocks are mainly solid magmatic rocks and metamorphic rocks with high mechanical strength and good engineering geological characteristics.

Rock mineral composition stability, not easy to resolve out of heavy metals and other harmful components. The geothermal gradient of the deposit is normal, no radioactive material is found, there is no big pollution source nearby, and the drainage of the mine pit, the dumping of ore debris and tailings have no obvious influence on the geological environment of the mining area. The terrain of the mining area is flat. Landslide, collapse, mountain torrents, mud-rock flow and other geological disasters will not occur in the natural state and the future mining activities. Mine drainage will drain part of the groundwater, in some areas of the formation of mining funnel. The chloride ion content and mineralization degree of groundwater in the mining area increased greatly, and the hydrogeological conditions in some areas changed to some extent.

\section{Conclusion}

To sum up, according to the occurrence characteristics of the main ore bodies in the Xincheng gold mining area of Jiaodong city and combined with the water ripple and geological conditions of the mining area, it can be seen that there is no pollution in the vicinity of the mining area, the ore and waste rock are not easy to decompose harmful substances, no heat harm; The possibility of local surface deformation caused by mining is not very great, the old holes and underground caverns formed in the past by civil mining have the possibility of local surface deformation or cave-in, and the scale and harm are small, in a certain extent, the groundwater depression funnel has been formed, the groundwater circulation is poor, the evaporation is large and the water quality is poor. The type of environmental geological exploration in the mining area is comprehensively assessed as a deposit with good geological environment condition.

\section{References}

[1] YANG Min-zhi, The geochemistry of wallrock alteration zone of gold deposits-As exemplified by Jiaodong gold deposits [M] Beijing: Geological Publishing House, 1998: 1-90.

[2] ZHAO Hai, ZHAO Ke-guang, MA Yao-li, XIU Chun-hua. Characteristics of Geological Structure of the Xincheng Gold Deposit, Jiaodong, And Direction In Gold Prospecting at Depth [J]. Journal of Geomechanics, 2004, 10 (2): 129-136.

[3] LV Gu-xian, GUO Tao, LIU Du-juan. Geological and structural Characteristics of Linglong-Jiaojia type gold deposit and factor analysis of their metallogenic tectonic physicochemical parameters: Exemplified by Fushan gold deposit [J]. Acta Geosicientia Sinca, 2002, 23 (5): 409-416.

[4] Peng Yongming, Zhao Hai, Guo chunying, etc.. Geochemistry characteristics of the Xincheng gold deposit in Jiaodong [J]. Journal of Geomechanics, 2013, 19 (1): 63-70.

[5] Wang Guangqiang. Ore-controlling factors and deep prospecting prediction of Xincheng gold deposit, Shandong Province. Kunming University of Science and Technology, 2011, 16-28.

[6] Wang Longzhen, Zhao Hai. Enlightenment for seeking concealed orebody in Jiaodong Gold deposit-taking Xincheng gold deposit as an example [J]. Golden Science and technology, 2008, 16 (4): 25-28.

[7] Wang Wenyu. The geological features and prospecting potential of the Xincheng gold deposit in Jiaodong Area. [J]. World Nonferrous Metals. 2021. 2: 65-66.

[8] Shi Lei. Analysis on geological characteristics and prospecting marks of Shandong Xincheng Gold deposit [J]. World Nonferrous Metals. 2019. 3: 98-100.

[9] Fu Qiubo, Miao Wenxue, Fu Dianwu, etc. Analysis of occurrence charateristics and minable amount of residual ore in No.1 orebody of Xincheng Gold mine [J]. Modern mining. 2021, 37 (4): 73-75.

[10] Shao Xuewei, Peng Yongming, Wang Gongwen, etc. Application of SWIR, XRF and thermoelectricity analysis of pyrite in deep prospecting in the Xincheng gold orefield, Jiaodong peninsula. Earth science frontiers, 2021, 28 (3): 236-251. 
[11] Yang Liqiang, Li Ruixue, Gao Xue, etc. A preliminary study of extreme enrichment of critical elements in the Jiaodong gold deposits, china. Acta petrologica sinica, 2020, 36 (5): 1285-1314.

[12] Song Mingchun, Cui Shuxue, Jiang Hongli. metallogenic structural system for Jiaojia gold field and Jiaoxibei gold deposits concentraled areas in shandong province, china $[\mathrm{J}]$. Geological Bulletin of china, 2011, 30 (4): 573-578.

[13] Zhao Peng Yun, Gu Xuexiang, Can Xue. Genesis and metallogenic model of Jiaojia gold deposit, Shandong Province [J]. Geology and Prospecting, 2007, 43 (4): 29-35.

[14] Guo Tao, Lv gu-hyun. system analysis on ore-controlling structure in the northwestern Jiaodong gold metallogenic belt [J]. Journal of Geomechanics, 2007, 13 (2): 119-130.

[15] Wang Xudong, Wang Zhongliang, Peng Yongming, etc. Wang Xudong, Comparison of I and V orebody characteristics and prospecting prediction of Xincheng gold deposit [J]. China Science and Technology Information, 2012, 17: 42-44. 